\title{
What is the type species of the genus Paenibacillus? Request for an Opinion
}

\author{
B. J. Tindall \\ Tel: +49 5312616 224. Fax: +49 5312616 418. e-mail: bti@dsmz.de
}

DSMZ - Deutsche Sammlung von Mikroorganismen und Zellkulturen $\mathrm{GmbH}$, Mascheroder Weg $1 \mathrm{~b}$, D-38124 Braunschweig, Germany

\begin{abstract}
The taxonomic status of the type species of the genus Paenibacillus cannot be easily determined according to the rules of the Bacteriological Code since the rules may be interpreted in an ambiguous way. Depending upon how the rules are applied the type species may be either Paenibacillus polymyxa or Paenibacillus durus. In addition, depending upon the way in which the Bacteriological Code is interpreted, the question of whether the name $\boldsymbol{P}$. durus (Collins et al. 1994) has been validly published must also be addressed.
\end{abstract}

Keywords: Paenibacillus, Request for an Opinion, Bacteriological Code
Ash et al. (1993) proposed that members of 'group 3' within the genus Bacillus should be transferred to the genus Paenibacillus. The type species of the genus was proposed as Paenibacillus polymxya. These proposals were subsequently published in the International Journal of Systematic Bacteriology in the Validation Lists (see Ash et al., 1994, 1995). However, Collins et al. (1994) also proposed that Clostridium durum should be transferred to the genus Paenibacillus, for which the orthographically correct combination is Paenibacillus durus. Although Collins et al. (1994) make clear reference to Ash et al. (1993) in proposing the transfer of Clostridium durum to the genus Paenibacillus, the principle of priority, based on page numbers in the same issue of the International Journal of Systematic Bacteriology causes confusion concerning which species is the type of the genus Paenibacillus. Valid publication of the name Paenibacillus polymyxa, the proposed type of the genus Paenibacillus (see Ash et al., 1993) occurs in the International Journal of Systematic Bacteriology 44 (1994), p. 852. However, the name Paenibacillus durus appears in the same issue, but on p. 824. Interpretation of the Bacteriological Code is not unambiguous concerning whether the species $P$. durus or $P$. polymyxa is the type of the genus Paenibacillus. The following points need to be taken into consideration:

(1) based on priority of publication the combination $P$. durus has priority over $P$. polymyxa (if both are validly published and legitimate);

(2) Rule 20c states that 'if the genus when originally (effectively and validly) published included one species, then that species is the type species.' This would apply to the combination $P$. durus in Collins et al. (1994);

(3) Collins et al. (1994) make clear reference (pp. 821 and 824) to the genus Paenibacillus and its formal description (effective publication) in Ash et al. (1993). Rule 27(1), (2) and (3) and Rule 33a do not explicitly require that a name must be formally proposed as 'Paenibacillus gen. nov.' Rule $28 \mathrm{~b}$ cannot be invoked because the genus is clearly proposed and accepted by Ash et al. (1993) and Collins et al. (1994);

(4) The question which arises is whether the name Paenibacillus is validly published by Collins et al. (1994), or whether the name is validly published in the Validation Lists (Ash et al., 1994).

Depending on when the name Paenibacillus is considered to be validly published, the type species is either $P$. durus or $P$. polymyxa. This has a number of consequences for nomenclature in this group of organisms.

(1) If valid publication of the name is considered to have occurred in Collins et al. (1994), then the type of the genus is $P$. durus, and the proposal to make $P$. durus a junior subjective synonym of Paenibacillus azotofixans contradicts Rule 15.

(2) If valid publication of the genus Paenibacillus is considered to have occurred in the Validation Lists, then the publication of the combination $P$. durus occurred at a time when the genus name Paenibacillus had not been validly published in or prior to the work of Collins et al. (1994). If this is the case for the combination $P$. durus (Collins et al., 1994), then valid publication of the name cannot be considered to have 
taken place and does not have standing in nomenclature. Recognition of the synonymy of $P$. azotofixans and Clostridium durum by Rosado et al. (1997) has, however, interesting consequences for the correct name of this taxon. Rule 42 governs the union of taxa of equal rank and states that the oldest legitimate name or epithet is to be retained. In this case the taxa Clostridium durum and P. azotofixans are subjective synonyms, but applying Rule 42 would make Paenibacillus durus the senior subjective synonym. The problem which now arises is that the combination Paenibacillus durus has not been validly published and it has no authors, unless it is considered to have been created by Rosado et al. (1997) on recognizing the synonymy of the two taxa. It should be noted that although the proposal to make $P$. azotofixans the senior subjective synonym by Rosado et al. (1997) is not in line with the Bacteriological Code, it does not make the name illegitimate. Similarly, if the name Paenibacillus durus is not considered to be validly published in Collins et al. (1994), the combination is not illegitimate and the name may be validly published but authorship would not be attributed to Collins et al. (1994). The Judicial Commission is asked to provide a ruling on the date of valid publication and authorship of the genus name Paenibacillus and the species name Paenibacillus durus.

This, and similar problems, may be avoided in the future if suitable changes are made to the Bacteriological Code which would require authors to clearly indicate that a new genus is being proposed when a name is validly published in the International Journal of Systematic and Evolutionary Microbiology (formerly International Journal of Systematic Bacteriology). Such changes must clearly state that the creation of a new species or a new combination in a new genus must be accompanied by the formal proposal (effective) and valid publication of the new genus either at the time of, or prior to valid publication of new species or new combinations within that genus (see Tindall, 1999).

\section{Acknowledgements}

I would like to thank Drs H. Hippe and N. Weiss, DSMZ, for critical reading of the manuscript.

\section{References}

Ash, C., Priest, F. G. \& Collins, M. D. (1993). Molecular identification of rRNA group 3 bacilli (Ash, Farrow, Wallbanks and Collins) using a PCR probe test. Antonie Leeuwenhoek $J$ Microbiol 64, 253-260.

Ash, C., Priest, F. G. \& Collins, M. D. (1994). Paenibacillus polymyxa comb. nov. In Validation of the Publication of New Names and New Combinations Previously Effectively Published Outside the IJSB, List no. 51. Int J Syst Bacteriol 44, 852.

Ash, C., Priest, F. G. \& Collins, M. D. (1995). New combinations Paenibacillus alvei, Paenibacillus amylolyticus, Paenibacillus azotofixans, Paenibacillus gordonae, Paenibacillus larvae, Paenibacillus macerans, Paenibacillus macquariensis, Paenibacillus pubuli, Paenibacillus pulvifaciens and Paenibacillus validas. In Validation of the Publication of New Names and New Combinations Previously Effectively Published Outside the IJSB, List no. 52. Int J Syst Bacteriol 45, 197-198.

Collins, M. D., Lawson, P. A., Willems, A., Cordoba, J. J., Fernandez-Garayzabal, J., Garcia, P., Cai, J., Hippe, H. \& Farrow, J. A. E. (1994). The phylogeny of the genus Clostridium: proposal of five new genera and eleven species combinations. Int $J$ Syst Bacteriol 44, 812-826.

Rosado, A. S., van Elsas, J. D. \& Seldin, L. (1997). Reclassification of Paenibacillus durum (formerly Clostridium durum Smith and Cato 1974) Collins et al. 1994 as a member of the species $P$. azotofixans (formerly Bacillus azotofixans Seldin et al. 1984) Ash et al. 1994. Int J Syst Bacteriol 47, 569-572.

Tindall, B. J. (1999). Proposals to update and make changes to the Bacteriological Code. Int J Syst Bacteriol 49, 1309-1312. 